\title{
IN SEARCH OF 'ISLAMIC LIFESTYLE'
}

\author{
Karim D. Crow*
}

\begin{abstract}
The question of what is an 'Islamic' way of life demands a thoughtful response in light of the growing material affluence of the middle class in many Muslim societies. The Qur'ān projects a detailed portrait of the Muslim individual and how to live a good life exemplifying Islamic precepts. In the view of the author, the possible contribution of Islamic values for shaping an emerging Cosmopolitan civilisation now confronts a new reality where Muslims are beguiled by the lifestyle of consumption. This emerging middle class appears to be content with embracing an Islamic surface identity. Are they being herded into the passive embrace of the consumer society?
\end{abstract}

And those who, when they spend, are neither extravagant nor niggardly but pursue an upright moderate living (sufficient to meet one's needs) (Qur'ān 25:67).

\section{Introduction}

How may one live life guided by Islam's values and teachings - or what is an Islamic way of life? This question demands a thoughtful response in light of the growing material affluence of large sectors of many Muslim societies in the twentyfirst century which eagerly embrace consumerism as central to their lifestyle. The personal and communal ideal for consciously living a good Muslim life embraces living one's life in harmony with divine directives intended to ensure collective security, well-being and fulfilment for our present bodily existence, as well as for that of future generations and the created order of nature. Beyond the flourishing of our personal lives and societies, and the life of our children and grandchildren, Islam expands the horizon to include the future existence in the immaterial realm. The Qur'ān emphatically stresses a basic distinction between two realms of existence: the 'seen' and the 'unseen' (shahädah and ghayb) - embodied physical existence and the immaterial or spiritual realm - expressed also in the contrast between 'this worldly life' and the 'life in the Hereafter' (al-duny $\bar{a}$ and al-äkhirah). The unique quality of the human creature is the possibility to inhabit both realms of existence through realising definite potentialities implanted in our being.

Muslims upholding this faith-based view of the created order, with its special function for human beings in a providentially designed order, need not offer an apology

* Karim D. Crow is Principal Research Fellow at IAIS Malaysia. 
when affirming the reality of the immaterial mode of existence. This conviction links life conduct and behaviour in the embodied realm with our status and future well-being in non-material existence. This may contradict the prevailing worldview and underlying assumptions of Late Modernity which only recognises and values the social, biological and economic dimensions of the animal (or creature) termed 'human', viewing consciousness, meaning and value merely as neuro-biological byproducts exhibited by material bodies - mere 'mental events'. Yet even this default materialist assumption termed 'physicalism' (dressed up as a logical corollary to European science upheld as the universal standard of 'truth') is under question and slowly yielding to more holistic multi-dimensional understandings among certain Anglo-European circles. A transformed understanding of being human may offer fresh perceptions of how our existence embodies energies and realisations-of-meaning beyond the horizontal plane of our bodily sensory platform and biological organism. Instinct, emotion and cognition are integrally joined in the integral human experience of meaning and purpose - and when properly coordinated yield potentialities opening out onto hierarchical planes of existence.

Just at this juncture when the possible contribution of Islamic values for shaping the future of an emerging Cosmopolitan age in the wake of the Enlightenment project, Muslims appear beguiled by the rise of a culture of affluence, with its lifestyle of consumption. We may now be experiencing a generational moment in which Islam could conceivably offer a genuine alternative to the ongoing marketisation of societies and rationalisation of human enterprises yielding environmental nihilism and clouding prospects for future growth and well-being. ${ }^{1}$ Yet this moment might well be passing Muslims by. Are they instead being herded into the passive embrace of the consumer society directed by the elite cliques at the helm of global neo-liberal capitalism? In search of what an Islamic lifestyle represents for Muslim consumers, and what way of life Islam upholds as worthy for human dignity and life satisfaction, we first look at the term 'lifestyle', then glance at values espoused by the Qur'àn, and next examine the expectations of middle class Muslims and the civilisational implications of Islamic consumption.

\section{Lifestyle}

What does lifestyle convey to Muslim consciousness in the twenty-first century? Being a relatively recent coinage in English, the term 'lifestyle' now carries particular meanings reflecting the values of modernity and material way of life shaped by marketisation of societies with its quantitative measures of human needs and goals bequeathed by nineteenth-century Positivism with its twentieth century offspring Rationalisation. ${ }^{2}$ Behind this reality, an audible echo of faintly articulated experience of the Muslim past still persists, exerting a certain weight. It is important 
to understand how the contemporary notion of 'lifestyle' has emerged to capture the attention and imagination of the growing middle class in many Muslim societies. More important may be recovering the legacy of Islamic life-conduct now obscured by the contemporary notion of lifestyle with its abundant commercial exploitations.

Two words conjoined - 'life' and 'style' - convey this modern meaning. ' 'Life' includes among its well established meanings "condition or manner of living", long employed in English to denote the earthly state of worldly physical existence-in contra-distinction to a future life or existence after death. The context is the religious contrast between two states of human existence separated by bodily death: our embodied life in this world, and our mode of existence in the Hereafter. (This double dimension of life is frequently evoked in the Qur'ān as the polarity of al-hayāt aldunya and al-ākhirah). In common contemporary usage, 'life' connotes human activity by a recognised member of society experiencing conspicuous pleasures and trials while engaged in practical pursuits of physical existence. 'Life' now is most frequently understood to refer only to this worldly life, while its other-worldly dimension has atrophied if not evaporated almost entirely in the prevailing dominant discourse.

'Style' in English signifies among other things, "a mode of deportment or behaviour; a mode of fashion of life, esp. in regard to expense, display, etc." 4 Such a meaning is relatively recent, appearing only from the late eighteenth century onward in several closely related usages. ${ }^{5}$ This social context clearly reflects class distinctions of the wealthy upper class (e.g., he lived "in a high style" or "a great style") as well as aspirations by the bourgeoisie to emulate the upper class. Closely linked to this societal class context is the extension of meaning to cover personal material display where style embraces "fashionable air, appearance, deportment" as well as "splendidly, showily, according to fashionable requirements" (e.g. 1874: "This is what the modern British public thinks is "living in style""). Flowing from this linguistic conceptual background, the two terms were joined together in more recent usage yielding our present widely employed concept of lifestyle. In the twentieth century the concept of lifestyle was employed by mercantile and commercial enterprises providing goods and services for the rising European and North American middle classes. These newly affluent classes invested potent consumerist energy into cultivating and acquiring a sought-after way of life reflecting material aspirations embodying an imagined identity. ${ }^{6}$

\section{Being Islamic?}

We now attempt to respond to the question: What is Islamic about the conduct of life for the individual and the community? Today the word 'Islamic' is over-used and frequently abused, exhibiting all the characteristics of a fetish deployed to secure 
imagined benefits and ward off unwanted associations of secularity and materialism, ${ }^{7}$ while grasping for a patina of religious relevance and cultural authenticity. Most contemporary Muslims wish to preserve an aura of authenticity when responding to dramatic pressures on their cultural, social and institutional existence imposed by rampant globalisation. The integration of information technology in trade, banking, info-entertainment media and digital communications has tremendously accelerated the pace and scope of globalisation. This acceleration has uprooted traditional societies and orphaned peoples from their parent meaning-systems, without integrating the peripheral peoples into the prevailing world system on equal power terms of cultural validity. Pervasive Euro-American dominance in so many arenas of contemporary life, from technology to the media to higher education and development planning, severely strains the inner stability of individual Muslim self-awareness and communal integrity. Simultaneously, this suffocating dominance agitates increased impatience toward Muslim peoples for not directly engaging wholly with secularist materialism and marketised social structures. These contradictory reactions are quintessentially symptomatic of our generational moment.

Therefore, the manner in which Muslims re-imagine Islam in terms of their own proper mode of 'being modern' may serve as a revealing index to their search for meaning and relevance brought about by modernity. ${ }^{8}$ However, many contemporary Muslims are sensitised to this very topic of 'being modern', interpreting any probing into their manner of embracing modernity as somehow implying they are not actually 'modern'. That is to say: 'modern' according to the prevailing standards projected by European and American societies - standards to which Muslims unconsciously submit and blindly adopt as valid benchmarks by which to measure themselves, without asking themselves if being Islamic and modern could find expression through alternative forms of social organisation, economic and financial structures, and institutional bodies aiding them to be true to themselves and their own tradition. ${ }^{9}$ This has important consequences for development goals and policy choices pursued by governments. We may place their sense of being left behind to one side, by remembering that modernity is in fact a plural reality: all of us are modern, and there are multiple modernities which include non-Western ways of being modern. ${ }^{10}$

Islam (as religion-faith-ethic) may risk losing its vital individual significance and effective communal purpose by submersion within a quasi-religion stressing ritualised conformity and simplistic exclusivist dogma. Religion as an ethical, intellectual and spiritual orientation with its corresponding range of practical and theoretical disciplines is now becoming more difficult to properly implant and cultivate among youth. Religious life may thereby be sidetracked and diverted into inclusive group identities cultivating parochial social practices ritually re-enacted from the past and clinging to external markers emblematic of a sought-for Islamic identity. This is particularly evident today in Muslim societies where growing affluence is shaping 
personal lifestyle choices of the expanding consumer class. There is an obvious risk that middle class consumption could collapse religious beliefs and observances into external markers of a desired Islamic identity wherein religious symbols become an outward commodity for acquisition.

\section{Living Islam}

There exists a polarity or a reciprocal tension between human identity and lived values, with each informing and enlivening the other to sustain a shared world-image and sense of self-purpose. Values are what endow human life with meaning and purpose, serving as building blocks of individual and communal identity. One must be careful to distinguish between permanent universal values not conditioned by time or place or limitations of a particular society; and those peripheral cultural norms and preferences (also often called by people today values) that are really only expressive of culturally conditioned behaviours relative to specific times, places and peoples. Perhaps one could offer the example of the highly esteemed value of chaste conduct, and the specific custom of women's face-shrouding in certain Muslim societies (e.g. the burqa in Afghanistan). Proper understanding of values leads to the recognition of a cluster of universal values arranged in a particular hierarchy - in other words, values possess a definite priority within a hierarchical scale bound together forming chains of values. As the late Professor Syed Hussein Alattas stated: ${ }^{11}$

Values are the building bricks to construct society. One must know how to combine the bricks into a structure, and this leads to the issue of the quantity and quality of the cement, and of how to mix and apply the cement that binds the hierarchy of values together. What is missing today is an understanding of this binding element-the cement - of values. Contemporary science and the 'humanism' of Western cultural modernity are deficient in both the quantity and quality of the bond that arranges universal values into an authoritative hierarchy.

An example: from an Islamic perspective justice is often seen as a primary core value within the hierarchical scale of values, since other values arrange themselves around justice. The universal values and precepts to be upheld and taught should be clearly evident in the lived behaviour of their practitioners, their exemplars or living examples. Otherwise, one is dealing with hypocrisy, with hollow words lacking any effective conative force, that fail to touch and move us from within, and thus fail to manifest any genuine observable change of behaviour. ${ }^{12}$

Values therefore are at the heart of how we live our lives, what we choose to embrace as essential, and our interior ways of being and external conduct. Our actions, choices and policies should (in the best scenario) mirror our deepest convictions and values. However, what one often experiences today is the opposite - false wants and 
misguided choices inversely provoking an upside-down scenario where the values truly motivating and shaping our choices might actually exhibit an un-Islamic mode of knowing and way of being. ${ }^{13}$ This contradiction forms one of the great ironies of Muslims being modern, while yet striving to live Islamic. In order to clarify this contradiction, we attempt to very briefly sketch what universal timeless values are taught by Islamic faith-ethic. We focus on the larger picture by reminding ourselves of the primary traits of a life lived displaying conduct and behaviour upheld by Islam as religion-faith-ethic. Then we might contrast these with the underlying values inherent in current middle class consumption and the culture of affluence now taking root in many Muslim societies.

The Qur'ān projects a detailed portrait of the good Muslim individual and how to live a life exemplifying Islamic precepts. ${ }^{14}$ Fundamental are performing good deeds and shunning evil deeds, observing sensible conduct, and behaving in a humble, restrained and compassionate manner. Seriousness, sincerity, hard work and discipline, and a high sense of urgency in worldly affairs, laying aside the trivial superficialities of making more money or amassing material objects, are held up as the model. Looking after one's ultimate self-interests, while guarding the true interests of one's fellows and one's environment, is of primary importance. Self-sacrifice, service to others, and striving for a higher cause requires placing the welfare of the whole community at a premium. A wrongdoer is termed zălim li-nafsihi, 'acting unjustly toward one's own self'. Purity is paramount - organic cleanliness (tahārah) and chaste pudency (haya ${ }^{\prime}$ and 'iffah) as well as the psychic purity of healthy emotions and productive thoughts, and preservation of unsoiled social and ecological surroundings. Strongly emphasised is the virtue of taqwā, 'God-mindfulness', often misleadingly translated as 'fear' but more accurately comprehended as 'reverential awe' or 'awareful consciousness' of divine guidance in terms of a "true sense of responsibility." 15

Key to such selfless conduct is $i h s \bar{a} n$, 'acting in the best manner', and ' $a d l$, 'behaving justly' or qist, 'equitable conduct'. Highly valued are qualities of steadfastness or long-suffering (sabr), and tranquil detachment (hilm) or 'patient forbearance' when moved by bodily passions and psychic needs. The faithful person ( $m u^{\prime}$ min - from $\bar{\imath} m \bar{a} n$ 'faith') is cautious about displaying prideful self-conceit (' $u j b)$, and seeks to show good qualities for the sake of divine good-pleasure and approval - not for winning approbation from others. Loving-kindness, selfless consideration for the best interests of others, and merciful compassion shown towards their weaknesses and shortcomings are stressed. Forgiveness and reconciliation are esteemed for healing ruptures, ensuring unity, and for safeguarding communal harmony.

The true Muslim lives life with a self-image of being a servant of God ( ${ }^{c} a b d$, pl. 'ibād Allāh), with a deep recognition of one's creaturely status, and the debt owed to the Creator for the priceless gift of life endowed with all our beneficial 
human faculties - senses, physical needs and satisfactions, pure emotions, activated intelligence, and wise understanding. Gratitude (shukr) for the gracious bounty and endowments provided by the source and origin of all life in creation is the proper human response to our physical embodiment and life in this world. The faithful person is conscious of the limited short-term worth of worldly material things, and evermindful of the overriding importance of seeking the good-pleasure of their Creator. Love of knowledge is privileged, along with respect for nature and for the dignity of peoples of all races, matched by awareness of one's accountability before God. The self-cultivation of humility, liberal generosity, sincere thankfulness, and service to one's fellows, combined with a sceptical attitude toward human pretensions and powers, is highly recommended. The conscious recognition of personal error and shortcomings is matched by genuine trust in divine forgiveness and compassionate acceptance, and a confident hope for guidance and growth in understanding. To scorn these manifold blessings by taking them for granted and using them merely to fulfil one's material needs without mindful awareness of the Creator's compassionate care and concern for all creatures is deemed 'un-faith' ( $k u f r$ ) or 'ingratitude'.

The person of un-faith (the käfir) is impetuously ungrateful, arrogantly prideful and boastful, self-conceited, brimming with wants and desires, and lacking proper judgement, real discernment, and innate self-control. The käfir or 'ingrate' is in the deepest sense foolish and ignorant (jähil and ahmaq) for spurning the guidance and knowledge of how best to live one's life which the Creator provides through dispatching prophets and messengers. Such self-centred people are concerned only with their own needs and preferences, loving the part, not the whole. Even when they practice generosity towards others, their generosity is tainted by excess and self-centred interest - an outward show to demonstrate their superiority over others and win acclaim. The outer success, wealth and power of the ingrate hides his inner weakness and lack of personal uprightness, reflecting ultimate ignorance of truthregardless of worldly sophistication or material success. His excess in amassing worldly goods and status is marked by waste and profligate indulgence (isra $\bar{f}$ - the musrif) which leads to imbalance and corruption ( $f a s \bar{a} d$ - the $m u f s i d$ ), yielding tyranny and injustice. Rather, sharing of wealth and equitable distribution of material resources (e.g., through zakāt and șadaqah) discourage hoarding and promote social progress, while contentment and frugality $\left(q a n \bar{a}^{c} a h\right.$, rid̄a $)$ are prized ideals.

One's attitude toward pursuing and disposing of wealth should be one of provident economising and thrifty management (iqtișād and iṣlāh) by taking a median course ( $i^{c} t i d \bar{a} l$ and qiwām) between wasteful excess and stingy miserliness. Moderation (wasatiyyah) and balance between extremes form the bedrock of human existence, and indeed of all creation. ${ }^{16}$ Profligate excess and immoderate indulgence of appetites (whether physical or psychic) encourage disorder and conflict resulting in insecurity and bloodshed. Excessive waste results in the opposite of just peace and equitable 
security, and is firmly condemned in the Qur'ān. ${ }^{17}$ In-group patronage, corruption and unethical exploitation for personal gain are actively discouraged. Legitimate profit taking must be complemented with an active sense of social responsibility and of personal moral obligation to society and to the planetary environment created by God, especially when pursuing institutional and infrastructure development. The model society Islam advocates supports neither unfettered market capitalism nor socialist uniformity, instead upholding an organic model of society where distributive justice may be effectively implemented, by which individuals may enjoy their right to personal property in a socially responsible manner that benefits all. ${ }^{18}$

Above all, the Qur'ān and the Prophet Muhammad's comprehensive teachings and personal example (his sunnah) exemplify the practical, ethical and spiritual requirements of the "Good Life" in all its manifold dimensions. The pursuit and maintenance of balanced well-being requires promoting and deepening knowledge, education, and training of one's self $(a d a b)$. Wholesome integrated living in balanced moderation, so central to the image of the good Muslim, involves the cultivation of the human soul and its virtues. The real goal of knowledge and its various applications includes individual realisation through perfection of Soul, as well as transforming society by rectifying imbalance and restoring the lawful order of creation. Islam's apprehension of the pursuit of the Good Life for attainment of ultimate felicity and happiness $\left(s a^{c} \bar{a} d a h\right)$ facilitates the true realisation of human potential and fulfillment. The dynamic interrelationship between the deepest aspects of the innate human constitution (fitrah) and the overriding worth of the dignity of human individuals, articulates a holistic image of the person in all his or her hierarchical dimensions. Qur'ānic and prophetic ethics offer the means by which the Soul may reach maturity and wisdom and attain salvation and ultimate success (najāt).

Traditional Islamic religious and intellectual traditions emphasise complementary aspects flowing out of this qur'ānic and Prophetic instruction: legal practice centres on ritual observances and regulating boundaries of behaviour for social harmony; theology focuses on authoritative doctrine and right guidance; Sufism highlights inner purification and cultivating love, unifying the individual with the universe and the Creator, while philosophic wisdom (hikmah) upholds the centrality of rationality for understanding the system of creation and rendering an adequate response to divine guidance. Normative Islamic ethics ( $a k h l a \bar{q}$, also adab) integrates many key aspects of these traditions in a harmony of faith, reason, and compassion crowned by understanding. ${ }^{19}$ This all-encompassing spiritual ethic within Islam has grown to synthesise the various traditions of practice and learning to mediate a multidimensional portrait of the Islamic way of life. The ground in which this spiritual ethic is rooted comprises the discipline of interior training and personal growth to maturity in human virtue exemplified by knowing and practicing the numerous virtuous character-traits (khuluq, pl. makārim al-akhlāq) best demonstrated by the 
model character of the prophets themselves, and conceived as sourced in the divine: "Adorn yourself with the virtuous character-traits of God" (takhalluq bi-akhlāq Allāh) in the words of a famous hadìth. Finally, it must be observed that this ethicospiritual practice was understood to form the necessary complement and fulfilment of the shari 'ah and jurisprudence, and that practicing legal disciplines without the crowning completion of the science of virtues was viewed as deficient one-sided practice. ${ }^{20}$

It is true that most Muslims rarely exemplify fully all those admirable qualities in an integrated manner, yet being Muslim and pursuing an Islamic way of life entails aspiring to shape oneself in the mould these values impart. Falling short of the ideal is not an original sin (an alien notion for Islam); imperfect and wayward creatures may cling to the conviction that divine guidance and compassion are ever present once they turn toward their Creator with a humbly sincere heart. Neither should Muslims rest content with merely being Muslim - active faith (īmān) and inner understanding or certainty (yaqin) are the most highly valued goals. After this simplified and generalising sketch of what the Islamic way of life comprises, we train attention on a profound social and economic reality reshaping the lives of many Muslims.

\section{Middle Class Asians}

Over the past two decades increasing attention is being devoted to the role of middle class consumption as a key driver of global capitalism, and how this impacts the integration of Muslim societies into global economic market activities and commercial strategies. In March 2012, The Economist Intelligence Unit published its report (commissioned by Kuwait Finance House), The Sharia-Conscious Consumer: Driving Demand, ${ }^{21}$ underlining the growing importance of the shart ${ }^{2} a h$-conscious consumer market, with sharicah-compliant products translating into healthy sales. Muslim majority countries are experiencing the fastest-growing demand: Arabian Gulf states, North Africa, and South Asia. The increasing acceptance of Islamic precepts is most evident in the halāl industry, Islamic finance, halāl-friendly tourism, and Islamic fashion, while the global haläl and Islamic finance industries (e.g. $s u k \bar{u} k$ bonds, and $\operatorname{sharĭ}^{c} a h$-compliant lending) are witnessing the fastest growth. In particular, Islamic finance is deemed a crucial facilitator for the whole of shari ${ }^{c} a h-$ based enterprises. These are not without major barriers and difficulties. Serious attention is now being paid to better management and training for product and service providers, smoother delivery and communication mechanisms, standardisation of labelling and convincing branding, and especially certification procedures with global validity. To become a player in this newly arisen global market, the values of integrity, community, and compassion to which Muslims aspire need to be invoked. Certain countries like Malaysia and Turkey are actively engaged in staking out 
leading positions, yet major investment bodies and transnational corporations in the West command the largest slice of the pie.

One must not forget the course of social and economic conditions in historical perspective since the rise of Europe in the eighteenth century with the spread of capitalism on the heels of imperialism. Modernising developments since the end of the eighteenth century up to the present in the realms of science, technology, mass education, huge bureaucratic state administrations, spreading urbanisation, the uneven emergence of civil societies with public spheres, new forms of mass media, mass production and consumption, and transformed gender relations have all impacted Islamic thinking and behaviour in Muslim majority societies. Conversely, Islamic thought and practices have shaped or affected the pace and course of these developments within specific societies. One should also consider the ways in which these global processes are related to external forces of colonialism, introduction of secular political and social ideologies, and globalisation in general, as well as to the persistence of embedded traditional customs, cultures and ways of life. Nevertheless, one may not ignore the reality of a monolithic urban environment promoted by the marketisation and rationalisation of production and consumption central to corporatedriven capitalism. The increasing sameness of urban spaces supporting similar socioeconomic patterns of life is an outstanding feature of Late Modernity, and undoubtedly represents the predominant living conditions for an increasing majority of humans.

The shift of economic and political power toward the emerging economies over the past two decades signals a new global reality of shifting wealth, with the growth of the global middle class in the South (or developing world) forming an outstanding marker of changes transpiring in the global economy. Homi Kharas (Brookings Institute, Washington DC) provides recent data on the rising consumerism of the global middle class, suggesting that Asia's emerging middle class will replace the United States as driver of the global economy by 2030 through compensating for falling growth in the US middle class. ${ }^{22}$ The indices for determining the middle class vary arbitrarily relative to social designation, economic classification, or human capital variables such as education, infant mortality, life expectancy and household savings and consumption. ${ }^{23}$ The World Bank, for example, employed an absolute definition for middle class as those with incomes falling between the mean level in Brazil and Italy - US $\$ 4,000$ to US $\$ 17,000$ in 2000 purchasing power parity (PPP) terms. ${ }^{24}$ Kharas focuses on the consumer class in 145 countries comprising 98 per cent of the world's population with 99 per cent of its GDP, making projections based on his assumption of no change in income distribution in the middle of the population, and measuring the middle class in terms of consumption levels.

By examining the cross-country distribution of income, Kharas defines the global middle class to consist of "those households with daily expenditures between US\$10 and US\$100 per person in purchasing power parity terms". He also projects "the 
global middle class growing by 4.6 per cent in real terms in spending power, and by 5.3 per cent in terms of number of people between now and 2020. ${ }^{25}$ In other words, Kharas privileges "the concept of purchasing power and the market for consumer goods and services" ${ }^{26}$ as the key characteristic of the middle class. He determines that in 2009 the global middle class comprised 1.8 billion people concentrated in North America (338 million), Europe (664 million) and Asia (525 million) - which breaks down into individual countries as, e.g., 230 million in the United States, 450 million in the European Union, and 125 million in Japan. (Sub-Saharan Africa is the region with the least number of middle class consumers). Such figures mask differences in purchasing power, with the North American middle class accounting for significantly more of global spending than its population share, ${ }^{27}$ while the reverse is currently true of the Asian middle class.

Table 1 The Global Middle Class, 2009: People and Spending

\begin{tabular}{lrrrr} 
& \multicolumn{2}{c}{$\begin{array}{c}\text { Number of People } \\
\text { (millions and global } \\
\text { share) }\end{array}$} & $\begin{array}{c}\text { Consumption } \\
\text { (billions PPPUSD and } \\
\text { global share) }\end{array}$ \\
\hline North America & 338 & $18 \%$ & 5,602 & $26 \%$ \\
Europe & 664 & $36 \%$ & 8,138 & $38 \%$ \\
Central and South America & 181 & $10 \%$ & 1,534 & $7 \%$ \\
Asia Pacific & 525 & $28 \%$ & 4,952 & $23 \%$ \\
Sub-Saharan Africa & 32 & $2 \%$ & 256 & $1 \%$ \\
Middle East and North Africa & 105 & $6 \%$ & 796 & $4 \%$ \\
World & 1,845 & $100 \%$ & 21,278 & $100 \%$ \\
\hline
\end{tabular}

(Source: Homi Kharas, "The Emerging Middle Class in Developing Countries," OECD Development Centre Working Paper No. 285 (Paris: Organisation for Economic Cooperation and Development, January 2010), available online at http://www.oecd-ilibrary.org/ (accessed on 10 June 2012), 16.

Table 1 estimates that in 2009 the Asia Pacific region comprised 28 per cent of the world's population, and 23 per cent of the global share of consumption. However, in twenty years time this same region might comprise 66 per cent of the global middle class, and spend 59 per cent of the global share of consumption (measured in millions of 2005 PPP dollars). This scenario is based on Kharas' estimate that the size of the middle class could increase from 1.8 billion people to 3.2 billion by the year 2020, and up to 4.9 billion people by the year 2030 - with almost all of this growth (ca. 85 per cent) occurring in Asia, while the size of the middle class in North America would remain roughly constant, and eventually decline over time in Europe. 
Table 2 Number (millions) and Share (percent) of the Global Middle Class

\begin{tabular}{lrrrrrr} 
& \multicolumn{2}{c}{$\mathbf{2 0 0 9}$} & \multicolumn{2}{c}{$\mathbf{2 0 2 0}$} & \multicolumn{2}{c}{$\mathbf{2 0 3 0}$} \\
\hline North America & 338 & $18 \%$ & 333 & $10 \%$ & 322 & $7 \%$ \\
Europe & 664 & $36 \%$ & 703 & $22 \%$ & 680 & $14 \%$ \\
Central and South America & 181 & $10 \%$ & 251 & $8 \%$ & 313 & $6 \%$ \\
Asia Pacific & 525 & $28 \%$ & 1,740 & $54 \%$ & 3,228 & $66 \%$ \\
Sub-Saharan Africa & 32 & $2 \%$ & 57 & $2 \%$ & 107 & $2 \%$ \\
Middle East and North Africa & 105 & $6 \%$ & 165 & $5 \%$ & 234 & $5 \%$ \\
World & 1,845 & $100 \%$ & 3,249 & $100 \%$ & 4,884 & $100 \%$ \\
\hline
\end{tabular}

(Source: Homi Kharas, "The Emerging Middle Class," 28).

The most striking scenario is the growth in purchasing power of the global middle class: it might swell from US\$21 trillion to US\$56 trillion by 2030 , with over 80 per cent of this growth in consumer demand coming from Asia. ${ }^{28}$ Of course Kharas emphasises that these figures are "not a projection or forecast" but merely "one scenario of what the world could look like" 29 when we try to envision the implications of the significant shift in the global economy towards Asia. The dominant shift is one to the East in the southern hemisphere: "over time, in our scenario for the future, it is India, China, Indonesia and Vietnam that keep pulling the centre of economic gravity in the world to the East." 30

Flowing from his growth scenario is the expectation of a steep increase in Asian demand driven by middle class consumption over the coming decades as the population becomes more urban, wealthy and educated, reflecting an accelerating trend of "the replacement of US demand by Asian demand." 31 Such an expansion of middle class consumers goes hand in hand with changing values of middle income families conducive to economic development who choose what they will consume, where "growth is driven by product differentiation, branding and marketing" in the new growth markets of Asia. (Although he never mentions the Muslim middle class, it is clear that $\operatorname{shari}^{\mathrm{c}} a h$-compliant industries possess a special niche as a growth market, with their own branding and marketing requirements.) Kharas argues that global economic recovery may well be spearheaded by the large rapidly growing Asian middle class with its "sharp upsurge in demand" who will "usher in a new era of rapid progress" fuelled by Asian consumers - ensuring an era of plenty that "does not depend on a rebound in US consumer demand." ${ }^{32}$ It is a rosy scenario bringing good cheer to trans-national corporate interests in the post-Great Recession era of the twenty-first century. The expanding growth markets in Asia, where Asian consumers could account for over 40 per cent of middle class consumption worldwide, will sustain global growth for the medium term. The venerable Enlightenment belief in 
unending material progress is affirmed. Nowhere is mentioned in this scenario the ecological footprints of so numerous an expanding consumer class, nor the social and human costs this might entail, or who might be left out from benefitting from expanded consumption.

Other voices echo Kharas' optimism, yet upholding the key role of Asian markets for a possible remoulding of global capitalism while also raising the warning of ecological damage to our planet through unrestrained pollution. Chandran Nair (founder of an independent think tank, Global Institute For Tomorrow/GIFT) points to the limits to growth and harmful effects of unrestrained consumption. ${ }^{33}$ With the spectacular rise in Asian living standards well underway, must the billions of new Asian consumers unthinkingly replicate Euro-American consuming patterns? Recall that the legacy of Western free-market capitalism spread by globalisation with its wasteful resource-intensity and externalising of social and environmental costs, has led to financial, social and ecological crises destructive of alternative values and forms of wealth. ${ }^{34}$ Instead of urging the Asian middle classes to consciously consume more and thereby save the global economy (as Kharas appears to do), should not policy makers and societal leaders be thinking hard about the difficult choices to be made in order to achieve a fundamental change of direction? Nair strongly suggests that the burgeoning Asian middle class occupies a unique position to effect such a fundamental reorientation - if they possess the political will, wisdom and fortitude to sustain this reorientation, and if their leaders are guided more rationally to seek their nations' true self-interests and act more competently.

The global economy to be dominated by Asian peoples could undertake eminently pragmatic shifts towards low-carbon green economies and resource efficiency, taxing waste and pollution, down-sizing financial transactions, and smoothing the path with risk-reduction investments to a more equitable human-friendly future. Nair makes a strong persuasive case for replacing mass consumption and waste and obsolescence based on capital and resource intensity, with lived values of economical conservation and prudent management of resources informed by an ecologic conscience grounded on our deepest ethical values. His work is a very serious rebuttal of the notion that consumption-driven capitalism is the proven system to deliver wealth most efficiently - bluntly stating that "in Asia, it can only deliver short-term wealth to a minority; in the long term, it can only deliver misery to all." ${ }^{" 35}$ Nair is convinced that Asian governments must elaborate and implement their own authentic modes of constrained consumption in order to have a realistic chance for genuinely sustainable development uplifting all their people. He is so focused on the need to curtail mass consumption that he is not afraid to propose regulation of advertising and redirecting it towards inculcating alternative forms of satisfaction.

It is ironic that the expected market resurgence of Asia conforms to a long established reality which goes against ingrained Eurocentrism blind to the long 
historical dominance of Asia in the global system. ${ }^{36}$ Asia accounted for more than half of world output for 18 of the past 20 centuries, and its growing clout in the world economy is actually a restoration, not an innovation. ${ }^{37}$ However, will the return of Asia to a central position in the global economy conform to business as usual, or may alternative values and world views be enabled to operate?

\section{Alternative Scenarios of Consumption}

There are other conflicting scenarios by keen observers who point to the necessity of an alternative strategy of development rather than the path of capitalist accumulation pursued till now. Samir Amin, the Egyptian-French Marxian developmental economist, gives a stringent analysis of the destructive dimensions of capitalist accumulation. ${ }^{38}$ The prevailing market economy necessarily results in a marketised society that nullifies citizenship and replaces it with a malleable mass of consumers as passive spectators. ${ }^{39}$ In many domains of human life, the pervasive tendency of global capitalism toward commodification and privatisation in pursuit of profit is now utterly transforming human existence on our planet: natural resources, health, education, pension funds, scientific research, as well as intellectual, industrial, cultural and artistic property. The chief feature of these tendencies inherent in the global expansion of capitalism is the abandonment of basic precautions and ethical concerns, immeasurable waste, the banality of homogenisation of culture, ecological nihilism, and political polarisation on a world scale. Amin argues that the inevitable consequences of this "logic of accumulation" with its destructive effects have become so severe that they "constitute a real threat to the future of humanity" and pose "a veritable crisis of civilisation." 40 He observes that the true dilemma confronting the vast majority of humanity in the peripheral countries is whether to play the game of catch-up, or to strive to build a different human social reality by de-linking from the centre through self-reliance and asserting cultural authenticity by means of democratisation.

While the impact of capitalism upon our natural environment (global warming) is often discussed and has aroused a trans-national community of Green activists, Amin draws attention to the threat posed for agriculture by the rise of "oligopolistic control over farmers' agribusiness" and the Earth's three billion peasants. He examines the transformation of agriculture under the present system of marketised globalisation: ${ }^{41}$ Capitalist Agriculture (governed by the principle of return on capital) is located almost entirely in North America, Europe, Australia, and the southern zone of Latin American, employing several dozen million farmers with large landholdings and mechanisation enabling them to achieve output between 10,000-20,000 quintals of cereal-equivalent per worker/year (or 1-2 million kilograms of cereals per farmer annual productivity). However, peasant agriculture includes almost half of humanity 
- three billion humans - divided between those who have benefitted from the Green Revolution (fertilizer, pesticide, seed selection, etc.) and achieve 100-500 quintals per worker (or 10,000-50,000 kilograms of cereals per year), and those who continue to operate with older methods and remain stuck around 10 quintals per head of active population [or 1,000 kilograms of cereals per farmer annual productivity). Amin draws the obvious conclusion from this incontrovertible data in starkly pessimistic terms:

The productivity gap between the best-equipped agriculture and the poorest peasant agriculture has shot up from 10:1 before 1940, to 2,000:1 today. In other words, the rate of productivity growth in agriculture has largely exceeded that in other areas of the economy, bringing with it a fall in real prices from 5 to 1 . In these conditions, to accept the principle of competition for agriculture and food products (as the WTO demands) is to accept that billions of 'uncompetitive' producers will be eliminated in the brief historical space of a few dozen years. What will become of these billions who, though already mostly the poorest of the poor, have in the past been able to feed themselves well or badly? [...] Today we have reached a stage of polarisation at which most of the world's population is 'superfluous' to the needs of capital... rural worlds have disintegrated under the impact of 'the market', and new forms of industrialisation have been incapable of absorbing the exodus of the village poor. With the help of all these factors, capitalism is taking us towards a 'shantytown planet' within the next 20 years, when 25 megalopolises will each pack in 7 to 25 million people reduced to abject poverty without any prospects for the future. Is this anything else other than the destruction of whole peoples? [...] It is hard indeed to conceive how the model of waste peculiar to capitalism could be extended to a world population around ten billion. ${ }^{42}$

Now this is quite a different scenario from that provided by the OECD we reviewed above. Are there any contributions to be drawn from the Islamic experience which may be relevant for addressing this immediate and urgent problem? Are Muslim thinkers and leaders capable of bringing to bear Islam's civilisational ethos in the search for an equitable social and economic order for half of humanity? What is the responsibility of Muslim middle class consumers in addressing this problem?

Warnings about unanticipated harmful outcomes of marketised-driven economic policies have been continually raised for over two decades by leading observers of societies and knowledgeable critics of development strategies, who advanced the priority of essential human requirements and ideals over enrichment of financial cliques through unfettered growth. ${ }^{43}$ Recent efforts stress the imperative to change the course of development strategies by arriving at agreed-upon criteria for measuring social well-being and human progress. The French government's initiative "Commission on the Measurement of Economic Performance and Social Progress" published in September $2009^{44}$ urged planners and policy makers to move away from 
GDP indices to much broader concerns encompassing social, environmental and economic sustainability. The just released report by the Royal Society in London, People and the Planet (April 2012), ${ }^{45}$ sounds a clear warning bell regarding the interlinked dynamic of rapid population growth in the poorest countries coupled with over-consumption in rich countries. The international group of experts who collaborated on this report emphasises how critical our present generational moment really is if our planet is to flourish in the Cosmopolitan age, with profound changes for human health and well-being and the natural environment. The Royal Society asserts that humanity has already moved beyond safe planetary boundaries on biodiversity loss, climate change, and the nitrogen cycle - risking severe impacts in the near future. Sir John Sulston, the report's chairman, affirms: "Where we go is down to human volition - it's not pre-ordained, it's not the act of anything outside humanity, it's in our hands!" 46

Eliya Zulu, the executive director of the African Institute for Development Policy in Nairobi, also cautioned: "Of the three billion extra people we expect to have, most will come from the least developed countries, and the population of Africa alone will increase by two billion." If the fertility rate in the poorest countries is not reduced to levels comparable to more wealthy countries, then global population by 2100 might reach 22 billion, of whom 17 billion would be Africans - largely peasants uprooted from the land and crowded into urban shanty towns. The priority should be to lift the world's poorest 1.3 billion people living on less than US $\$ 1.25$ daily out of extreme poverty, empower women and invest heavily in family planning, child and maternal health and in universal education. Simple measures that must be taken include eliminating food waste, reducing fossil fuel burning, and transforming economies from goods to services. Indicators of economic health must abandon the use of GDP as determinative and adopt measures which privilege natural capital, the goods and services freely provided by nature. The report suggests that for the poorest countries the best thing would be increased consumption of food, water and other resources while the richest nations reduce the resources they are consuming; otherwise our world will become much more unequal. Indeed, numerous signs of over-consumption such as obesity and food waste are appearing in a number of middle income countries, not to mention the proliferation of shopping malls.

Current unprecedented levels of material consumption pose profound challenges to human health and the well-being of our planetary environment. The realisation that the most affluent societies and the emerging economies must stabilise and then reduce material consumption levels through drastic changes in resource exploitation and by decoupling economic activity from ecological degradation has begun to take root in thinking circles. Several publications by the Worldwatch Institute (the authoritative American California-based think tank for research and policy solutions on critical global issues) stress the need to move from consumerism to sustainability 
by means of a conscious cultural transformation which involves re-examining affluent people's lifestyles. ${ }^{47}$ In its most recent State of the World 2012 this institute offers a study on "The Path to Degrowth in Overdeveloped Countries"48 which recommends "degrowth" for economies beyond the limits of their ecosystems - the intentional redirection of economies away from the perpetual pursuit of growth. Degrowth requires the most affluent wasteful societies to shift away from their consumerist culture in a controlled planned contraction so as to harmonise with planetary limits, moving towards a steady-state economic system in balance with Earth's boundaries. In other words, obese societies must undertake a crash diet. Rather than celebrating the shifting of wealth to the East, what may be needed is a reduction of wants and curtailment of desires.

\section{Muslims and Consumption}

So what does an Islamic lifestyle entail in the global age of the consumer society with its rapidly growing halāl and Islamic financial industries? Three years ago Professor Vali Nasr ${ }^{49}$ published Forces of Fortune (2009), an overview of the significance of the growing Muslim middle class. His book was immediately reprinted under the title The Rise of Islamic Capitalism: Why the New Muslim Middle Class is the Key to Defeating Extremism (Free Press, 2009), and then printed again with this title by the Council on Foreign Relations in 2010. Vali Nasr's book was also updated and republished under the title Meccanomics: The March of the New Muslim Middle Classes (New York: Oneworld, 2010). It has received highly favourable reviews, ${ }^{50}$ and it appears that his work is being seriously promoted. Its front flap describes it as "a paradigm-changing revelation" and "groundbreaking analysis", informing us that the author "reveals that there is a vital but unseen rising force in the Islamic world - a new business-minded middle-class - that is building a vibrant new Muslim world economy and that holds the key to winning the cold war against Iran and extremists." This blurb goes on to portray "a Muslim world in which the balance of power is being reshaped by an upwardly mobile middle class of entrepreneurs, investors, professionals, and avid consumers - who can tip the scales away from extremist belligerence."

Despite this lurid publishing pitch to entice sales, and notwithstanding one's initial impression that Professor Vali Nasr's book intends to convey the reassuring message to American readers that Muslims are being won over to their value system by sheer force of the market, his work is informative and insightful. Nasr portrays the important consumerist impulse sweeping more affluent Muslim societies, whose significance he argues is worthy of serious attention. He observes:

[A] vital economic transformation [is] underway all around the region - the rise of a new middle class that is the key to more fully integrating the Middle East into the global 
economy, and to the building of better relations with the West. It is to this rise of a new middle class that leaders in the United States and around the world should turn attention - to fuel its potential - rather than allowing the chimerical power of fundamentalism to dictate so much of its approach to the region. ${ }^{51}$

Vali Nasr views the cultural and religious concerns bubbling in the Muslim Middle East as basically driven by economic and socio-political realities. He describes the potential for marketisation and the attraction of consumerist values in several countries ranging from Dubai, Turkey, and Iran, showing the vital blending of Islamic piety and capitalist conviction flourishing in many corners of the region. He correctly points out that Iran, despite its corrupt and inefficient centralised system suffocating 80 per cent of the economy, high inflation, and gutting of the private sector, nevertheless possesses great potential to join the consumer society. With its vast oil reserves, high literacy, strong industrial base, a web and cell phone savvy population,

around half of Iran's population of 70 million is middle class or above - counting their possessions, disposable income, level of education, and family size - with the kind of social attitudes that are needed to support robust consumption habits and modernising change. [...] The great battle for the soul of Iran - and the soul of the region as a whole - will be fought not over religion but over business and capitalism. ${ }^{52}$

Perhaps it is more than hyperbole that Iran's intellectual and political leaders envision Iran becoming an Islamic Japan and global economic force. Recall that before the Iranian revolution of 1979, this country was seen to be a potential "second Korea". Vali Nasr is correct when he states that

[a]ll over the Middle East piety is shaping consumption. [...] This upwardly mobile middle class consumes Islam as much as practicing it, demanding the same sorts of life-enhancing goods and services as middle classes everywhere. Their preference that those goods have an Islamic flavor makes Islam big business. A booming economic sector around the region is catering to this explosive demand, and these rising Islamic consumers comprise as much as a sixth of humanity. ${ }^{53}$

The same applies beyond the Middle East in the more affluent countries such as Malaysia and even Indonesia, and in Muslim minority communities of Europe and North America. When one walks into the ubiquitous glitzy shopping malls and up-scale retail establishments in many parts of the Islamic world, with eager shoppers buying the latest electronic gadgets, fashionable home furnishings, fast food, and new forms of leisure socialisation- the power of the market cannot be denied. Satellite television mesmerises millions, with religious debates aired and televangelists pandering to huge audiences, preaching modernity and business-friendly Islam, peppered with advertisements. At the prestigious Seventh World Halal Forum convened in Kuala 
Lumpur in April 2012, when I questioned a prominent British Muslim community leader whether he had any qualms about selling Islam as a product for consumption, his immediate and unequivocal reply was "It's a good product!" The non-Muslim global corporations and enterprises understand this well, since they hold the lion's share of the lucrative $\operatorname{shari}^{c} a h$-friendly markets. The Swiss food giant Nestlé is the largest purveyor of halāl foods on the planet; according to the World Halal Forum the European haläl market is estimated at US\$67 billion in 2010, when the Malaysian haläl market was reckoned at only US\$8.7 billion the same year. The books on Islamic branding and marketing constitute a small growth industry in itself. ${ }^{54}$

Nevertheless, one may take issue with Vali Nasr in his assumption that consumerist marketisation of Muslim societies is an unmitigated blessing, with consumption lifestyles ensuring their global integration into the prevailing globalised capitalist market. ${ }^{55}$ The portrait of the Islamic way of life taught by the Qur'ān presented above must be contrasted with the appetitive prodigality and conspicuous consumption seductively encouraged by global consumerism. As this writer observed elsewhere,

[...] selling an Islamic Lifestyle requires understanding the psychic needs and anxieties of consumers, and addressing their lifestyle choice by means of packaging those preferred Lifestyle components to ultimately function as fetishes and adornments. [...] The danger remains that prevailing forms of material consumption packaged as indigenous national Islamic identity, will continue to serve the marketising forces of trans-national corporations at the helm of global capitalism. Obsessive concern with purist halāl food consumption, outer dress or ritualistic practice, yields a banal form of Muslim modernity pervaded by shallow materialist consumerism subject to manipulation by corporate elites for maintaining power and wealth. Humans thus become outwardly more 'Muslim' yet inwardly less Islamic. This paradox lies at the heart of Islamic consumption. ${ }^{56}$

\section{Conclusion and Recommendations}

Where is the genuine Islamic alternative to laissez-faire marketisation and ethical relativism of Euro-American modernity? Achieving authentic Islamic modernity requires Muslims to rejuvenate ethical and social ideals harmonising faith with rationality, and material existence with the immaterial realm. Islam offers inalienable values which may guide Muslims today in countering the wasteful consumption culture of casino capitalism, the ecological nihilism degrading nature, or predatory militarism enforcing one nation's exceptional self-interest - all such unwholesome manifestations being rooted in a materialist anthropology which reduces humans to mere social and biological animals. Muslims today must acquire the skills to exploit the full breadth of their intellectual and spiritual resources in order to properly benefit from opportunities brought by globalisation and irreversible processes of world financial and cultural integration. 
Therefore, we appeal to Muslim government policy makers and society leaders to:

- carefully appraise and reflect upon consumption patterns in their society, in order to understand potential benefits, risks, and harms unfolding in their midst;

- $\quad$ perform a deeper scrutiny and comprehension of universal values manifested in religious conduct and experience in order to consciously awaken a living concern with Islamic resources when responding to the pressures of consumption and increased affluence; and to

- design procedures and methods which may nurture more restrained and selfcritical lifestyle choices within the prevailing consumerist environment.

\section{Notes}

1. For one assessment calling for a new set of values, see Graeme Maxton, The End of Progress: How Modern Economics Has Failed Us (Singapore: Wiley, 2011).

2. The term 'rationalisation' as used by Max Weber referred to the bureaucratisation of rational-legal authority; as employed by Jürgen Habermas, it currently connotes the application of instrumental reason where an increasing number of social actions are based on considerations of teleological efficiency, predictability and quantitative calculation, rather than on motivations derived from morality, emotion, custom, or tradition. Rationalisation constitutes a central aspect of EuroAmerican modernity and determines procedures and goals ranging from food production to higher education and supply of products and services. Parallel terms also widely used are 'marketisation', 'McDonaldisation', as well as 'commodification'. Further see George Ritzer, The McDonaldisation of Society (Los Angeles: Pine Forge Press, 2008).

3. This writer relies on meanings taken from The Oxford English Dictionary (Oxford: Oxford University Press, 1933; Compact Edition 1971), s.v. "life" def. IIIb; and "style" def. 25. The term 'lifestyle' itself did not occur in OED1; see, however, E. Ehrlich et al., Oxford American Dictionary (New York: Oxford University Press, 1980), 382.

4. The Oxford English Dictionary (1933 ed.), def. 25 A.

5. Ibid., c. 1780 "[...] living in the style of a gentleman;" 1788 "an opportunity of marrying in such a manner as would enable her to live in a certain style among a certain class;" and 1805 "what a style you do live in! what elegant curtains!"

6. A popular example was the American television program aired from 1984-1995, Lifestyles of the Rich and Famous, hosted by Robin Leach and created by Alfred M. Masini (who also created the successful programs Solid Gold and Star Search); it featured lush images of the extravagant lifestyles of wealthy entertainers, athletes and business moguls.

7. Treating something as a fetish means attributing inherent value and powers to any man-made material object, cultural product or symbol. Karl Marx first introduced the notion of commodity fetishism into European thought. See Karim D. Crow, "Consuming Islam: Selling 'Wholesome' as Lifestyle Fetish,” The Halal Journal [Kuala Lumpur] 42 (2012), 46-52. (The term fetish was originally used by colonial Europeans when describing African sacral-power artificial objects such as small idols, believed to be endowed with supernatural efficacy and employed for magical or prophylactic purposes.)

8. For representative overviews of varied Muslim responses to modernity consult John Cooper, 
Ronald Nettles, and Mohamed Mahmoud (eds.), Islam and Modernity, Muslim Intellectuals Respond (London and New York: I.B. Tauris Publishers, 2000), Clinton Bennett, Muslims and Modernity. An Introduction to the Issues and Debates (London and New York: Continuum, 2005), and insightful essays in Khalid Masud, Armando Salvatore, and Martin van Bruinessen (eds.), Islam and Modernity: Key Issues and Debates (Edinburgh: Edinburgh University Press, 2009).

9. On the 'catch up' theory of 'backwardness' - 'catching up' with the dynamics of Western-centred capitalism conceived as the highpoint of modernity and civilisation, see David Harvey, Spaces of Global Capitalism: A Theory of Uneven Geographical Development (London: Verso, 2006).

10. Shmuel Noah Eisenstadt, Comparative Civilisations and Multiple Modernities (Leiden and Boston: Brill, 2003, 2 vols.), introduced the notion of 'multiple modernities' as a cosmopolitan plural reality.

11. The late Professor Syed Hussein Alattas, in his presentation "The Way of Life and Universal Values" given at Soka Gakkai Malaysia, a lay Buddhist organisation, in Kuala Lumpur on 21 June 2003. This citation is based on my own notes.

12. For a discussion of the conative (efficacy-willing-impulse to manifest one's conduct) as well as the cognitive (knowing-perceiving-grasping) components of ethical action, see Karim D. Crow, "Islam and Reason," Al-Shajarah [Kuala Lumpur] 8, no. 1 (2003), 109-37. The crucial link between knowing and doing, or knowledge and virtue, lies in operating our conscience, which in early Islamic teachings was understood to be part of the operation of intelligence ( $a l^{-}{ }^{c} a q l$ ).

13. One might rephrase this inversion as an epistemic crisis, but it rather reflects a misguiding or misdirection where knowledge is corrupted - in religious terms, it is a 'leading astray'.

14. For good overviews of qur'ānic ethics in English, consult Toshihiko Izutsu, God and Man in the Qur'an (Tokyo: Keio Institute of Cultural and Linguistic Studies, 1964; repr. Kuala Lumpur: Islamic Book Trust, 2002); idem, Ethico-Religious Concepts in the Koran (Montreal: McGill University Press, 1966); Fazlur Rahman, Major Themes of the Qur'an (Minneapolis MN: Bibliotheca Islamica, 1980) pp.17-64, and passim. See further Martin R. Zammit, A Comparative Lexical Study of Qur'ānic Arabic (Leiden: Brill, 2002) - useful charts for key semantic fields of qur'ānic terms on pp. 47-51, which clarify the most important terms and concepts; thus the two largest semantic fields treat Soul and Intellect: 1) State of Mind $=8.07 \%$, and 2) the Will $=5.98 \%$, namely the cognitive and conative dimensions of behaviour.

15. See Rahman, Major, index s.v. taqwā.

16. For an insightful and comprehensive presentation of its importance, see Mohammad Hashim Kamali, Moderation and Balance in Islam: The Qur'annic Principle of Wasatiyyah (Kuala Lumpur: IAIS Malaysia, 2010, IAIS Malaysia Monograph Series No. 1).

17. Ibid., 32-34.

18. Consult Maxime Rodinson, Islam and Capitalism (Paris: 1966; rpr. London: Saqi Books, 2007), for a refreshing and contentious rebuttal of the reduction of Islam as anti-profit taking or worldrejecting. For a complementary perspective on the compatibility between Islam and capitalism, see Timur Kuran, The Long Divergence: How Islamic Law Held Back the Middle East (Princeton: Princeton University Press, 2010), who argues for the continuing relevance of Qur'ānic economic principles once liberated from stagnant inherited interpretation and practice. Both these authors maintain the ethical basis of economic practice as expounded by Islam.

19. On moral literature exemplifying Islamic understanding of values, most notable is the rich study by Charles-Henri de Fouchécour, Moralis: Les notions morales dans la litterature per- sane du 3e/9e au 7e/13e siecle (Paris: Editions Recherche sur les civilisations, 1986, Bibliothèque iranienne 32). The classical literature on virtuous character-traits is vast; one may explore its depths in alḤāfiz Aḥmad b. al-Ḥusayn al-Bayhaqī, Shucab al-īmān [Branches of Faith], ed. M. S. Basyūnī Zaghlūl (Beirut, 1990) in nine volumes, with chapters on every major praiseworthy character-trait collectively constituting the components of faith, and in a smaller scope the beautiful work by Ibn 
Ḥibbān al-Bustī, Rawḍtat al-'uqalā' wa nuzhat al-fuḍalā', ed. M. M. 'Abd al-Ḥamīd et al. (Beirut, 1977).

20. The necessity for $a k h l a \bar{q}$ as completion of fiqh is clearly evident in works by two leading ethicospiritual exponents: al-Rāghib al-Așbahān̄̄, al-Dharī a ilā makārim al-sharī̄ah [Expedient-Means to the Virtuous Character-Traits of the Divine Law], and his follower Abū Ḥāmid al-Ghazālī, Ihyā' 'ulūm al-dīn [Revival of Religious Sciences]. Furthermore, consult de Fouchécour, Moralis, and Ira M Lapidus, "Knowledge, Virtue, and Action: The Classical Muslim Conception of Adab and the Nature of Religious Fulfillment in Islam," in: B. D. Metcalf (ed.), Moral Conduct and Authority: The Place of Adab in South Asian Islam (Berkeley CA: University of California Press, 1984), 3861.

21. The Economist Intelligence Unit, The Sharia-Conscious Consumer: Driving Demand, commissioned by Kuwait Finance House (Economist Intelligence Unit Limited, March 2012); written by Nigel Gibson and directed by Trevor McFarlane. This report gathers data in the public domain, as well as thirteen in-depth interviews with executives of companies from the shari $\bar{l}^{c} a h$ industry, and an on-line survey of 398 executives worldwide.

22. Homi Kharas, "The Emerging Middle Class in Developing Countries," OECD Development Centre Working Paper No. 285 (Paris: Organisation for Economic Cooperation and Development, January 2010), 61 pp., available online at http://www.oecd-ilibrary.org/ (accessed on 10 June 2012).

23. See ibid., 10-13, for his review of literature.

24. "World Development Indicators" (Washington DC: World Bank, 2007), available online at http:// go.worldbank.org/U0FSM7AQ40 (accessed on 10 June 2012).

25. Kharas, "The Emerging Middle Class," 12, and 9. Kharas states: "Defined in this way, the global middle class excludes those who are considered rich in the poorest advanced countries and those who are considered rich in the richest advanced country." He admits to a degree of arbitrariness in defining the middle class using fuzzy globally comparative data, and he relies on the results of the 2005 International Comparison Program [jointly carried out by the UN-OECD-World Bankregional development banks] for setting Purchasing Power Parity terms, even while casting doubt on its results. However: "the focus should be on changes over time of the number of individuals falling into a specific category" (p. 13), so as to approximate the global distribution of income. See Kharas' data on pp. 14-16, "Measuring the Global Middle Class," relying on X. Sala-i-Martin, "The World Distribution of Income (Estimated from Individual Country Distributions)," Economics Working Paper 615, Department of Economics and Business, Universitat Pompeu Fabra.

26. Kharas, "The Emerging Middle Class," 15.

27. Kharas (ibid.) notes (p. 15): "The US is home to 12 per cent of the world's middle class in terms of absolute numbers of people, but it accounts for USD 4.4 trillion ( 21 per cent) of the USD 21 trillion in global spending by middle class consumers. The difference is because the US middle class is much wealthier than the average global middle class consumer."

28. Ibid., 25-29. Thus in Kharas' scenario: over this same period from 2009 until 2030 the share of global consumer spending in North America might decline from 26 per cent to 10 per cent, while that of Europe from 38 per cent to 20 per cent. See ibid, Table 3 on p. 28.

29. Ibid., 25 .

30. Ibid., 26.

31. Ibid., 28.

32. Ibid., 38-39.

33. Chandran Nair, Consumptionomics: Asia's Role in Reshaping Capitalism and Saving the Planet (Oxford: Infinite Ideas, 2011). Nair has an active career as an environmental consultant, advising governments and transnational corporations on policy, and strategic management coaching to business leaders. 
34. For critiques of neoliberal marketised economics behind corporate driven globalisation, one should consult: David Harvey, A Brief History of Neoliberalism (New York: Oxford University Press, 2007), Ha-Joon Chang, Bad Samaritans: The Myth of Free Trade and the Secret History of Capitalism (New York: Bloomsbury Press, 2008); and the classic work by John Gray, False Dawn: The Delusions of Global Capitalism (London: Granta Books, 2009; $4^{\text {th }}$ ed.).

35. Nair, Consumptionomics, 195.

36. For recent challenges to Eurocentric assumptions about the triumphant rise of Europe as herald of modernisation, see especially the prescient work by Andre Gunder Frank, ReORIENT: Global Economy in the Asian Age (Berkeley CA: University of California Press, 1998; $4^{\text {th }}$ printing 2002); as well as Kenneth Pomeranz, The Great Divergence: China, Europe, and the Making of the Modern World Economy (Princeton: Princeton University Press, 2001, rev. ed.).

37. Consult the comprehensive databases on indicators of growth and development compiled by the Groningen Growth and Development Centre, founded by Angus Maddison in the Economics Department of the University of Groningen. This data on quantitative macroeconomic history is invaluable; see his "Historical Statistics of the World Economy: 1-2008 AD," available online at http://www.rug.nl/feb/onderzoekscentra/ggdc/index (accessed on 10 June 2012). See furthermore A. Maddison, Contours of the World Economy 1-2030 AD. Essays in Macroeconomic History (Oxford University Press, 2007).

38. Consult e.g., Samir Amin, Capitalism in the Age of Globalisation, transl. Patrick Camiller (London and New York: Zed Books, 1997). Amin is a trenchant advocate of 'alternative-globalisation' who specializes in the social history of 'peripheral capitalism' in Africa and Asia.

39. This dehumanizing phenomenon has also been portrayed as a society of 'spectacle' or a hollow 'simulation' by certain European observers. See Guy Debord, The Society of the Spectacle (New York: Zone Books, 1995; French original 1967), and Jean Baudrillard, The Consumer Society: Myths and Structures (London: Sage Publications, 1998; French original 1970); as well as this writer's brief presentation in "Consuming Islam," The Halal Journal [Kuala Lumpur] 42 (2012).

40. See Samir Amin, Obsolescent Capitalism: Contemporary Politics and Global Disorder, transl. Patrick Camiller (London and New York: Zed Books, 2003), 154-58 ('Destructive dimensions of capitalist accumulation').

41. Ibid., 174-76 ('Capitalism and the agrarian question'). See also S. Amin, "World Poverty, Pauperisation and Capital Accumulation," Monthly Review 55, no.5 (October 2003).

42. S. Amin, 'Capitalism and the agrarian question', 175, 176, and 156-57. Further, see the report Planet Under Pressure by the UK's Commission on Sustainable Agriculture and Climate Change, chaired by Sir John Beddington (the UK's chief scientific advisor), released in March 2012. Numerous organisations have echoed these alarms in recent years, including Oxfam's report Growing a Better Future in May 2011, the UK government's Foresight Report on Food and Farming Futures in January 2011, and the 2010 Global Hunger Index produced by the International Food Policy Research Institute, Welthungerhilfe, and Concern Worldwide, as well as the Council of Food Policy for the British government in December 2008.

43. Notably Amartya K. Sen, whose notion of human development contributed to formulating the annual Human Development Report published by the United Nations Development Programme. See A. K. Sen (with Martha Nussbaum), The Quality of Life (Oxford: Clarendon Press, 1993). Also consult Zygmunt Bauman, Globalisation: The Human Consequences (Cambridge: Polity Press, 1998).

44. See the website of this Commission available online at http://www.stiglitz-sen-fitoussi.fr/en/index. htm (accessed on 10 June 2012). It was chaired and advised by Professors Joseph Stiglitz, Amartya Sen, and Jean-Paul Fitoussi. 
45. The Royal Society Science Policy Centre Report, People and the Planet (London: The Royal Society, April 2012), 134 pp.; also available online at http://royalsociety.org/policy/projects/peopleplanet/report/ (accessed on 10 June 2012). This report is coordinated with preparations for the Rio+20 Summit in Brazil in June 2012 which hopes to establish "sustainable development goals".

46. Reported by Richard Black on BBC World News, 26 April 2012: "Population and Consumption Key to Future" (also for the following citation from Eliya Zulu).

47. Worldwatch Institute, State of the World 2010. Transforming Cultures: From Consumerism to Sustainability, foreword by Muhammad Yunus (New York: W.W. Norton \& Co., 2010), with twenty-six articles from sixty prominent researchers on consumerism and cultural change; also available online at http://worldwatch.org/node/6096 (accessed on 10 June 2012).

48. Worldwatch Institute, State of the World 2012: Moving Toward Sustainable Prosperity, chapter 2 by Erik Assadourian, "The Path to Degrowth in Overdeveloped Countries," also available online at http://blogs.worldwatch.org/sustainableprosperity/wp-content/uploads/2012/04/SOW12_chap_2. pdf (accessed on 10 June 2012).

49. Vali Nasr is Professor of international politics at the Fletcher School of Law and Diplomacy, Tufts University, and adjunct senior fellow for Middle Eastern studies at the Council on Foreign Relations in New York. An American of Iranian origin, Professor Nasr has published several notable works on the Middle East on topics intersecting with US foreign policy.

50. As a sample, see John Parker, "Burgeoning Bourgeoisie: A Special Report on the Middle Class in Emerging Markets," The Economist, 14 February 2009, 6.

51. Vali Nasr, Meccanomics: The March of the New Muslim Middle Classes (New York: Oneworld, 2010), 23.

52. Ibid., $7 \mathrm{ff}$.

53. Vali Nasr, Forces of Fortune (New York, NY: Simon \& Schuster), 14.

54. See e.g., Paul Temporal, Islamic Branding and Marketing: Creating a Global Islamic Business (Singapore: John Wiley \& Sons, 2011), which includes an "Executive Summary of the Proceedings of the Inaugural 'Oxford Global Islamic Branding and Marketing Forum' held at the Saïd Business School, University of Oxford, 26-27 July 2010." Chapters include "Social Media Branding and the Muslim Lifestyle Consumer" (pp. 182-89), and "Build Your Brand with Islamic Values with Universal Emotional Appeal” (pp. 226-27). See furthermore Baker Ahmad Alserhan, The Principles of Islamic Marketing (Surrey UK: Gower, 2011).

55. For more theoretical comprehensive appraisals of Muslims in the glittering super-market of global consumerism, consult Johanna Pink (ed.), Muslim Societies in the Age of Mass Consumption: Politics, Identity and Culture between the Local and the Global (Newcastle Upon Tyne UK: Cambridge Scholars Publishing, 2009), whose sixteen chapters focus upon particular societies and products. Also see Johan Fischer, The Halal Frontier: Muslim Consumers in a Globalized Market (New York: Palgrave MacMillan, 2011) treating contemporary Muslim consumer culture in Southeast Asia and Europe.

56. Crow, "Consuming Islam," 50 